\title{
TURIZM REHBERLiĞi BIRINCI SINIF ÖĞRENCILERININ MESLEKI BEKLENTiLERI
} THE PROFESSIONAL EXPECTATIONS OF FIRST GRADERS IN

\author{
Dr. Ümit ŞENGEL \\ Sakarya Uygulamalı \\ Bilimler Üniversitesi \\ umitsengel@gmail.com \\ ORCID: 0000-0003-1284-836X
}

\author{
TOURISM GUIDANCE \\ Prof. Dr. Burhanettin ZENGiN \\ Sakarya Uygulamalı \\ Bilimler Üniversitesi \\ bzengin@gmail.com \\ ORCID: 0000-0002-6368-0969
}

öz

Turizm rehberliği birinci sınıf öğrencilerinin mesleki

beklentilerinin tespit edilmesi bu çalışmanın amacını oluşturmaktadır. Türkiye'de turizm ile ilgili bazı bölümlerin tercih edilmesinde sorunlar yaşanırken, turizm rehberliği tercih edilen bir bölüm olarak ön plana çıkmaktadır. Turizm rehberliğinin de diğer bölümlerin tercih edilmesiyle ilgili yaşanan sorunları yaşamaması adına bu tarz çalışmalar önem arz etmektedir. Çünkü son yıllarda Türkiye'deki üniversitelerde turizm rehberliği bölümleri hiçbir planlama olmadan açılmaktadır. Böyle devam etmesi durumunda gelecekte bölümün tercih edilebilirliği ile ilgili önemli sorunların ortaya çıkabileceği düşünülmektedir.

Araştırmada nicel araştırma yöntemleri kullanılmıştır. Veri toplama aracı olarak anket tekniğinden yararlanılmıştır. Çalışmanın araştırma evrenini Sakarya Uygulamalı Bilimler

Üniversitesi Turizm Fakültesi oluşturmaktadır. Veriler

Turizm Rehberliği bölümüne kayıtlı 100 öğrencinin

93'ünden ve yüz yüze olacak şekilde toplanmıştır.

Araştırmanın sonuçlarına göre öğrencilerin beklentilerinin olumlu olduğu tespit edilmiştir. Ayrıca öğrencilerin bazı beklentileri cinsiyet, bölümün istekli olarak tercih edilmesi ve ailelerin aylık gelirine göre anlamlı olarak farklılaşmıştır.

Araştırmanın sonuçlarına göre öngörülen sorunların yaşanmaması için konuyla bağlantılı paydaşlara öneriler getirilmiştir.

Anahtar kelimeler: Öğrenci, Turizm Rehberliği, Mesleki Beklenti

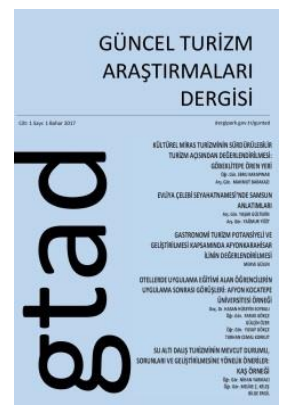

ABSTRACT
MAKALE BILGISi

Araştırma Makalesi Makale Geliş

21.06.2019

Düzeltme

30.09.2019

22.10.2019

Kabul

31.10.2019

The purpose of this study is to determine the professional expectations first year students of tourism guidance. while Problems in the choice of some departments related to tourism in Turkey, tourism guidance comes to the fore as a preferred section. Such studies are important in order for tourism guidance not to experience problems related to the preference of other departments because the tourism guidance department in universities recently opened without any planning in Turkey. In the event of such continuity, it is considered that significant problems may arise in the future.

Quantitative research methods were used in the study. Survey technique was used as data collection tool. Sakarya University of Applied Sciences Tourism Faculty is the population of the study. Data were collected from 93 out of 100 students recorded in the tourism guidance department. Data were collected face to face from the students. According to the results of the study, the expectations of the students were found to be positive. In addition, some expectations of the students differed meaningfully by gender, being preferred by the department and the monthly income of the family. In the context the results of the research, In order to avoid any problems, bring forward proposals for related stakeholders.

Key words: Student, Tourism Guidance, Professional Expectation

Atıf için: Şengel, Ü. ve Zengin, B. (2020). Turizm Rehberliği Birinci Sınıf Öğrencilerinin Mesleki Beklentileri. Güncel Turizm Araştırmaları Dergisi. 4(1), 38-53. 


\section{Giriş}

Turizm endüstrisinin 1950 'lerden sonra yaşadığı değişimler ve turizm pazarının giderek büyümesi, birtakım konularda bazı gelişmelerin yaşanmasını beraberinde getirmiştir. Bu konulardan en önemlilerinden birinin nitelikli personel ihtiyacı olduğu söylenebilir. Turizm endüstrisindeki gelişmelerle birlikte, turistlerin taleplerine ilişkin ihtiyaç, beklenti ve bilgi düzeylerinde önemli değişimler yaşanmıştır. Dolayısıyla gerek endüstriyel gelişmeler, gerekse de turistlerin bilinç düzeyinin artması turistlerin turistik hizmetlerden beklentilerinin yükselmesine neden olduğu düşünülmektedir. Bu durum turizm endüstrisinin ihtiyaç duyduğu nitelikli personel ihtiyacını daha da önemli hale getirmektedir.

Nitelikli personel ihtiyacının giderilmesi noktasında dünya genelinde turizm eğitimleri verilmeye başlanmıştır. Dünyadaki mevcut turizm pazarından pay alan ülkeler, bu paylarını daha fazla arttırmak için nitelikli personel ihtiyacının karşılanması amacıyla turizm eğitimine önem vermeye başlamışlardır. Türkiye de bu ülkelerin başında gelmektedir. Özellikle 1980'li yıllarda dışa açık ekonomi modelinin benimsenmesiyle birlikte, ülkede artan turizm hareketleri turizm yatırımlarının artışında büyük rol oynamıştır. Bunun bağlamda nitelikli personel ihtiyacının karşılanması için

Turizm Rehberliği

Birinci Sınıf Öğrencilerinin Mesleki Beklentileri 2000 'li yıllarla birlikte Türkiye'de turizm eğitiminin daha çok ivme kazandığı ve ülkede önemli bir endüstri olmasının yanında, bir akademik disiplin olarak turizmin gelişiminin hızlandığı söylenebilir. Birçok üniversitede meslek yüksekokulu, yüksekokul ve fakültelere bağı turizm ile ilgili bölümler açılmış ve bu bölümlerde akademik personeller istihdam edilerek öğrenciler yetiştirilmeye başlanmıştır. Özellikle 2010'lu yıllar itibariyle birçok üniversitede turizm fakülteleri kurulmuştur. Ancak iyi bir planlama yapılmadığından açılan turizm ile ilgili bölümler zamanla tercih edilmemeye başlanmıştır. Bu bölümlerden turizm kelimesi geçen bölümlerin tercih edilebilirliğinin azalmasıyla birlikte, gastronomi ve mutfak sanatları, turizm rehberliği ve rekreasyon gibi bölümler üniversitelerin bünyesinde açılmış ve öğrenci almaya başlamıştır. Bu nedenle birçok fakültelerde bu bölümlerin açılmasına hız verildiği görülebilmektedir.

Türkiye'de öğrenciler turizm ile ilgili bölümleri büyük beklentiler ile tercih etmektedir. Bu beklentilerin karşılanmaması sonraki dönemlerde ilgili bölümlerin tercih edilebilirliğini azaltabilmektedir. Öncellikle ülkede turizm endüstrisinde çalışan işletmelerin ücret ve özlük hakları konusunda iyimser bir anlayışa sahip olmamaları, kamusal istihdam konusunda diğer bölümlere oranla daha az avantaj sahibi olmaları, toplumsal yapının turizm ile ilgili mesleklere ilişkin sahip olduğu olumsuz bakış açısı gibi birçok sebep 
turizm ile ilgili bölümlerin daha az tercih edilmelerine sebep olmaktadır. Özellikle öğrencilerin üniversite eğitimlerine başlama şamasında sahip oldukları mesleki beklentilerin ortaya konması, eğitimin bu konudaki olası etkilerinin tespit edilmesi noktasında önem taşımaktadır. Turizm rehberliği öğrencilerinin mesleki beklentilerinin tespit edilmesi bu çalışmanın ana amacını oluşturmaktadır. Bu kapsamda araştırmanın turizm eğitimi literatürüne katkı sağlayacağı düşünülmektedir.

\section{LITERATÜR TARAMASI}

Beklenti kelime anlamıyla "gerçekleşmesi beklenen şey" anlamına

Ümit ŞENGEL ve Burhanettin ZENGIN, 4 (1) 2020

- 40 gelmektedir. Ayrıca "bireyin belli şart ve durumların alacağı biçimler veya kendisinden beklenenler konusundaki öngörüsü" şeklinde bir manaya da sahiptir. Bu yönüyle beklentiler hayatın her alanında ve farklı konularla ilgili olabilmektedir (TDK, 2019). Bireylerin bu beklentilerini eğitim, yaş, cinsiyet, değerler, gelenek ve görenekler, aile, kültür, toplum gibi birçok faktör şekillendirebilmektedir (Uluçay, vd., 2014: 235; Saw, vd., 2013). Prior ve Cox (2014) bu unsurlardan yaşı ön plana çıkarmış ve yaş faktörünün beklentileri belirleyen önemli bir unsur olduğunu vurgulamışlardır.

Öğrenci beklentilerinin ölçüldüğü çalışmalara literatürde sıklıkla rastlanılmaktadır. Bu çalışmalar genel olarak lise ve üniversite öğrencileri veya spesifik olarak üniversitelerde eğitim görülen bölümlerdeki öğrencilerle ilgili olabilmektedir. Lise öğrencileriyle ilgili yapılan çalışmalarda ailelerin öğrencilerin gelecek beklentilerini belirleyen en önem unsur olduğu tespit edilmiştir (Dilbaz ve Seber, 1993; Raffaelli ve Koller, 2005). Uluçay ve arkadaşları (2014: 234) lise öğrencilerinin gelecek beklentileri ilgili yaptıkları çalışmada önemli bulgular tespit etmişlerdir. Bu çalışmanın sonuçlarına göre eğitim görülen lise türü ve ailelerin ekonomik yapıları öğrencilerin beklentilerini belirleyen en önemli değişkenler olarak ön plana çıkmaktadır.

Üniversite öğrencilerinin beklentilerini ortaya koymaya yönelik çok farklı konu ve örneklemlerde çalışmalar yapılmıştır. Başta mesleki beklenti olmak üzere eğitimi sürecindeki başarı durumu, eğitim ortamının nitelikleri, alınan bilgi ve tecrübe gibi birçok faktörün bu beklentileri etkileyebilme gücüne sahip oldukları söylenebilir. Üniversite eğitimi boyunca bireyin değerleri, yaşam tarzları ve dünya görüşleri başta olmak üzere birçok önemli konuda farklılıklar ortaya çıkabilmektedir (Akman, 1992: 126). Öğrencilerin beklentileri bu farklılıklara bağlı olarak değişimler gösterebilmektedir.

Öğrencilerin geleceğe ilişkin beklentilerini araştıran çalışmalar incelendiğinde, gelecekle ile ilgili beklentiler önemli bir araştırma alanı 
olmakla birlikte, çalışmalar genel olarak mesleki beklentilere yoğunlaşmaktadır (Prior ve Cox, 2014; Şengel, cd., 2015). Çünkü öğrenciler üniversite eğitimleriyle birlikte mesleki kariyer anlamında bir yola girmekte ve bu yolda iş tecrübesi ve staj gibi uygulamalarla mesleki kariyerlerini şekillendirmektedir (Buyruk, 2009: 978; Dursun ve Aytaç, 2012: 374; Guest ve Duyen, 2016: 67). Olumlu olma durumuna bağlı olarak, bazı öğrenciler eğitimleri devam ederken bile meslek değiştirme eğilimine sahip olurken, bazıları eğitimden sonraki çalışma hayatından sonra böyle bir yola girmektedir. Bunun yanısıra turizm eğitimi alıp mesleki beklentileri karşılanan ve oldukça önemli noktalara gelen öğrencilerin de olduğunu ifade etmek gerekmektedir.

Son yıllarda Türkiye'de turizm eğitimi veren bölümlerin tercih edilmeleri ile ilgili yaşanan düşüşler ve bunların sebeplerinin ortaya konması kritik bir öneme sahiptir. Özellikle adında turizm geçen bölümlerin tercih edilmesinde düşüşler yaşanmaktadır. Bu düşüşlerin yaşanmasında, öğrencilerin mesleki beklentileri önemli rol oynamaktadır. Çünkü turizm eğitimi alan öğrencilerin eğitim esnasındaki staj veya iş deneyimleri beklentilerinin negatif olmasına zemin hazırlayabilmektedir (Eker, vd., 2015). Duman ve arkadaşlarının (2006) yaptıkları çalışmada, öğrencilerin turizm endüstrisindeki çalışma koşullarını ağır, ücret ve ek gelirleri düşük gördükleri tespit edilmiştir. Türkay ve Yağcı (2007) turizm eğitimi alan kişilerin sektörde uzun süre çalışmaya sıcak bakmadıkları ve ayrılma eğilimine sahip olduklarını ifade etmektedirler. Bu bulgu Zengin ve arkadaşları (2017) tarafından da desteklenmektedir. Fraser (2003) bu durumu personel devir hızı olarak değerlendirmekte ve düşük ücret, uzun mesai saatleri, vardiyalı çalışma sistemi ve iş stresi gibi faktörleri bunun sebepleri olarak ifade etmektedir. Bu tür faktörler öğrencelerin olumsuz beklentiye sahip olmaları ve söz konusu bölümlerin tercih edilebilirliğinde düşüşlerin yaşanmasını beraberinde getirdiği söylenebilir. Bu faktörlerin yanında fiziki çalışma koşulları, kalifiye olmayan yöneticiler, iş hayatının özel hayatı aksatması gibi faktörlerin de olduğu Gürkan ve arkadaşlarının (2010) yaptığı çalışma ile desteklenmiştir. Bu bulgular Kokt ve Strydom, (2014) çalışmasında yer alan bilgilerle de paralellik göstermektedir.

Turizm öğrencilerinin mesleki beklentilerinin olumsuz olduğunu tespit eden çalışmalar da literatürde kendine yer bulmaktadır. Zengin ve arkadaşları (2011) yaptıkları çalışmada olumsuz mesleki beklentileri tespit eden bu çalışmaları derlemişlerdir. Buna göre turizm bölümlerinden mezun olan öğrencilerin beklentileri genel olarak yüksek ve olumlu olmakla birlikte, çalışma hayatından sonra, endüstrideki çalışma şartları ve gelişim fırsatları konusundaki sınırlılıkları gibi nedenlerle yaptıkları işe motive olamadıkları ve bu nedenle işlerini terk etikleri ifade edilebilir.

Turizm Rehberliği

Birinci Sınıf

Öğrencilerinin

Mesleki Beklentileri 


\section{YÖNTEM}

\section{Araştırmanın Amacı ve Önemi}

$\mathrm{Bu}$ çalışmanın amacı birinci sınıfta eğitim alan turizm rehberliği öğrencilerinin meslekten beklentilerinin neler olduğunu tespit etmektir. Türkiye'de üniversitelerin ve turizm fakültelerinin giderek arttığı günümüzde, öğrenciler tarafından tercih edilmek gittikçe zorlaşmaktadır. Öğrenciler artık bilinçli olarak hareket etmekte ve üniversite eğitimi sonrasındaki mesleki yaşamlarını da düşünerek tercihlerde bulunmaktadır. Bu nedenle özellikle turizm ile ilgili turizm işletmeciliği, turizm işletmeciliği ve otelcilik, turizm ve otel işletmeciliği, konaklama işletmeciliği ve yiyecek içecek işletmeciliği gibi geleneksel bölümlere olan talebin azalması sonucu,

Ümit ŞENGEL ve Burhanettin ZENGIN, 4 (1) 2020 üniversitelerde eğitimi giderek önem kazanan ve talep gören turizm rehberliği gibi bölümlerin de aynı durumla karşılaşmaması için bu tür çalışmalar önem taşımaktadır.

\section{Araştırmanın Veri Seti}

Çalışmada nicel araştırma yöntemleri, veri toplama aracı olarak ise anket kullanılmıştır. Anket formu iki bölümden oluşmaktadır. Birinci bölüm Likert ölçeğine göre düzenlenmiş ve rehberlik birinci sınıf öğrencilerinin mesleki beklentilerini ölçen 27 ifadeden oluşmaktadır. Bu bölümdeki ifadeler en olumsuzdan (1-Kesinlikle Katılmıyorum), en olumluya (5-Kesinlikle Katılıyorum) doğru derecelendirilmiştir. Anketin ikinci bölümü ise öğrencilerin demografik özelliklerini yansıtan 7 maddeden oluşmaktadır.

\section{Araştırmanın Evreni ve Örneklemi}

Çalışmanın araştırma evrenini Sakarya Uygulamalı Bilimler Üniversitesi Turizm Fakültesi Turizm Rehberliği bölümü birinci sınıf öğrencileri oluşturmaktadır. Bu çalışma dört yıllık eğitim süresinin, öğrencilerin beklentilerine olan yansımaları şeklinde tasarlanmış olup bir süreç araştırmasıdır. Bu araştırma, ilerde yapılması planlan çalışmanın ön araştırmasıdır. Araştırmanın veri toplama sürecinde örneklem hesaplamasına gidilmemiştir. Araştırma evreninin küçük ve bir kontrol grubu olması, veri toplama sürecinin kolay olması ve çalışmanın bir süreç çalışması olması nedeniyle evrenin tamamına ulaşııması hedeflenmiştir. 2018-2019 eğitim öğretim yılında bölüme kayıtlı 100 öğrencinin 93'ünden veri toplanmıştır. Örneklem büyüklüğü açısından bakıldığında bu sayı yeterlidir. Çünkü \%95 güven aralığında (\% 5 hata payı) 100 kişilik bir araştırma evreninden 80 kişilik bir örneklemin olması yeterlidir (Yazıcıoğlu ve Erdoğan, 2004: 50). Veriler toplanırken aynı örneklemden sonraki zamanlarda da veriler toplanacağı için katılımcı öğrencilerin isimleri de alınıştır. Veri alınan öğrenciler çalışmaya gönüllü olarak katılmıştır. 


\section{BULGULAR}

Araştırma bulgurlarının elde edilmesinde istatistik analiz programından yararlanılmıştır. Verilere sıklık, farklılık ve güvenilirlik testleri uygulanmıştır. Araştırmanın güvenilirliği için Cronbach Alpha değerine bakılmış ve bu değer anketteki 27 ifade için 0,962 olarak tespit edilmiştir. Bu değer, sosyal bilimler açısından çalışmanın güvenilir olduğunu göstermektedir (Can, 2014: 369). Terzi ve Tercan (2007)'nın öğretmen adayı öğrencilerin tutumlarını ölçmek için kullandığı bu ölçeğin ilgili çalışmada güvenilirlik katsayısı (Alpha) 0,97 olarak tespit edilmiştir. Araştırmada kullanılan ölçek daha sonra Şahin ve Acun (2016) tarafından rehberlik mesleğine uyarlanarak rehberlik okuyan öğrencilere uygulanmıştır. Bu araştırmada ise güvenirlik katsayısı (Alpha) 0,96 olarak tespit edilmiştir. Araştırmada kullanılan ölçeğin daha önce yüksek güvenilirlik katsayılarına sahip araştırmalarda kullanılması ölçeğin geçerliliği için önemli bir referanstır.

Turizm Rehberliği

Birinci Sınıf Öğrencilerinin Mesleki Beklentileri

Tablo 1'de katılımcı öğrencilere ait betimleyici istatistikler yer almaktadır. Erkeklerin çoğunlukta olduğu katılımcıların yaklaşık \%90'nına yakını geldiği bölümden önceden haberdardır.

Tablo 1: Katılımcılara İlişkin Betimleyici İstatistikler

\begin{tabular}{lcclcc}
\hline DEĞiŞKENLER & $\mathbf{N}$ & $\%$ & DEĞiŞKENLER & $\mathbf{N}$ & $\%$ \\
\hline Cinsiyet & & & \multicolumn{2}{l}{ Ailede Rehber veya Turizm Çalışanı } \\
\hline Kadın & 39 & 41,9 & Evet & 13 & 14,0 \\
Erkek & 54 & 58,1 & Hayır & 80 & 86,0 \\
\hline Okul Öncesi Meslek Hakkında Bilgi & & Bölüme İsteyerek Gelme Durumu & \\
\hline Evet & 82 & 88,2 & Evet & 68 & 73,1 \\
Hayır & 11 & 11,8 & Hayır & 25 & 26,9 \\
\hline Aile Aylık Ortalama Gelir & & & Anne Mesleği & 60 & 64,5 \\
\hline 3000 Ł ve altı & 42 & 45,2 & Ev Hanımı & 6 & 6,5 \\
3000 Ł'nin üstü & 51 & 54,8 & Kamu & 14 & 15,1 \\
\hline Baba Mesleği & & & Özel Sektör & 13 & 14,0 \\
\hline Kamu & 19 & 20,4 & Diğer & & \\
Özel Sektör & 29 & 31,2 & & &
\end{tabular}

Katılımcı öğrencilerin \%86'sının ise ailesinde rehber veya turizm çalışanı bulunmazken, katılımcıların yaklaşık \%75'ine yakını bölüme isteyerek gelmiştir. Bu beklentilerin belirlenmesi ve gelecekte mutlu bir meslek hayatı açısından önemli bir veridir. Katılımcı öğrencilerin ebeveyn 
Ümit ŞENGEL ve Burhanettin ZENGIN,

4 (1) 2020

- 44

meslekleri incelendiğinde ev hanımı olan anneler çoğunluktayken, baba mesleklerinde diğer (emekli, esnaf, serbest meslek vb.) kategorisindeki meslekler çoğunluktadır. Son olarak ise, katılımcı öğrencilerin yaklaşık \%55'i 3000 もve üstü gelire sahipken, \%45'i 3000 も ve altı gelire sahiptir.

Tablo 2'de araştırmaya dâhil olan öğrencilerin beklentilerini ölçen ifadelerin sıklık değerleri yer almaktadır. Iffadeler katılım gücü göz önünde bulundurularak aritmetik ortalamalara göre büyükten küçüğe doğru sıralanmıştır. Aritmetik ortalamalara göre en yüksek katılımın olduğu ifadeler "insanlara gezdikleri bölgeyi tanıtacak olma düşüncesi beni mutlu ediyor", "rehberlik yapan kişilerle sohbet etmekten hoşlanırım", "rehberlik yapan insanlara sempati duyarım", "rehberliğin bir şeyler üretip yaratmam için bana fırsatlar vereceğini düşünüyorum" ve "rehber olmayı kendime yakıştırıyorum." ifadeleridir. Bu ifadelerin aritmetik ortalamaları 3,98-3,82 aralığında değerler almaktadır. Bu ifadelerin her biri rehberlikle ilgili olumlu görüşleri ortaya koyan ifadelerdir.

Aritmetik ortalamalara göre en düşük katılımın olduğu ifadeler ise "rehberliğin bana göre bir meslek olmadığını düşünüyorum", "rehberliğin yaşam tarzıma uygun olmadığını düşünüyorum", "rehberlik mesleği bana sıkıcı geliyor", "rehberlik mesleğini seçtiğime pişman oluyorum" ve "rehberliğin kişiliğime uygun olamadığını düşünüyorum" ifadeleridir. Bu ifadelerin aritmetik ortalamaları 2,26-2,12 aralığında değerler almaktadır. Tablo 2'de verilen maddelerin her biri rehberlik mesleği ile ilgili olumsuz beklentileri içermektedir. Bu veriler tablo 1'de yer alan öğrencilerin bölümü isteyerek tercih ettiklerini gösteren verileri de desteklemektedir.

Tablo 2: Araştırma ifadelerine iliş̧kin Sıklık Değerleri

\begin{tabular}{|c|c|c|c|c|c|c|c|c|c|c|c|}
\hline \multirow[t]{2}{*}{ IFADELER } & \multirow[b]{2}{*}{ A. 0} & \multicolumn{2}{|c|}{ 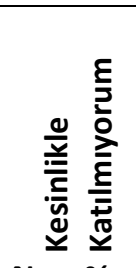 } & \multirow{2}{*}{\multicolumn{2}{|c|}{ 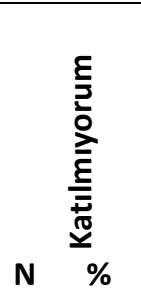 }} & \multicolumn{2}{|c|}{ 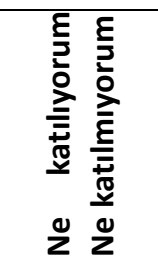 } & \multicolumn{2}{|c|}{ 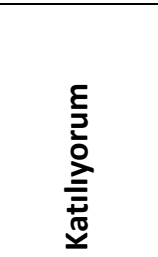 } & \multicolumn{2}{|c|}{ 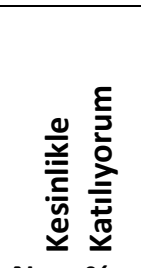 } \\
\hline & & $\mathbf{N}$ & & & & $\mathbf{N}$ & $\%$ & $\mathbf{N}$ & $\%$ & $\mathbf{N}$ & \\
\hline $\begin{array}{l}\text { İnsanlara gezdikleri } \\
\text { bölgeyi tanitacak olma } \\
\text { düşüncesi beni mutlu } \\
\text { ediyor. }\end{array}$ & 3,98 & 6 & 6,5 & 4 & 4,3 & 8 & 8,6 & 42 & 45,2 & 33 & 35,5 \\
\hline $\begin{array}{lr}\text { Rehberlik } & \text { yapan } \\
\text { kişilerle } & \text { sohbet } \\
\text { etmekten hoşlanırım. }\end{array}$ & 3,97 & 3 & 3,2 & 7 & 7,5 & 10 & 10,8 & 42 & 45,2 & 31 & 33,3 \\
\hline
\end{tabular}




\begin{tabular}{|c|c|c|c|c|c|c|c|c|c|c|c|}
\hline $\begin{array}{lr}\text { Rehberlik } & \text { yapan } \\
\text { insanlara } & \text { sempati } \\
\text { duyarım. } & \end{array}$ & 3,90 & 3 & 3,2 & 9 & 9,7 & 15 & 16,1 & 33 & 35,5 & 33 & 35,5 \\
\hline $\begin{array}{l}\text { Rehberliğin bir şeyler } \\
\text { üretip yaratmam için } \\
\text { bana fırsatlar } \\
\text { vereceğini } \\
\text { düşünüyorum. }\end{array}$ & 3,88 & 8 & 8,6 & 4 & 4,3 & 13 & 14,0 & 34 & 36,6 & 34 & 36,6 \\
\hline $\begin{array}{ll}\text { Rehber } & \text { olmayı } \\
\text { kendime } & \\
\text { yakıştırıyorum. } & \end{array}$ & 3,82 & 3 & 3,2 & 7 & 7,5 & 21 & 22,6 & 34 & 36,6 & 28 & 30,1 \\
\hline $\begin{array}{l}\text { Rehberlik mesleğinde } \\
\text { karşılaşacağım } \\
\text { zorlukları } \\
\text { aşabileceğime } \\
\text { inanıyorum. }\end{array}$ & 3,77 & 5 & 5,4 & 3 & 3,2 & 21 & 22,6 & 43 & 46,2 & 21 & 22,6 \\
\hline $\begin{array}{l}\text { Rehberlikte başarılı } \\
\text { olacağıma inanıyorum. }\end{array}$ & 3,74 & 5 & 5,4 & 5 & 5,4 & 20 & 21,5 & 42 & 45,2 & 21 & 22,6 \\
\hline $\begin{array}{l}\text { Bilgili ve yeterli bir } \\
\text { rehber olacağımı } \\
\text { düşünüyorum. }\end{array}$ & 3,74 & 4 & 4,3 & 4 & 4,3 & 24 & 25,8 & 41 & 44,1 & 20 & 21,5 \\
\hline $\begin{array}{ll}\text { Rehber } & \text { olma } \\
\text { düşüncesi bile } & \text { bana } \\
\text { cazip geliyor. } & \end{array}$ & 3,72 & 5 & 5,4 & 3 & 3,2 & 25 & 26,9 & 40 & 43,0 & 20 & 21,5 \\
\hline $\begin{array}{l}\text { Rehber olacağımı } \\
\text { düşünmek beni mutlu } \\
\text { ediyor. }\end{array}$ & 3,69 & 5 & 5,4 & 8 & 8,6 & 21 & 22,6 & 35 & 37,6 & 24 & 25,8 \\
\hline $\begin{array}{l}\text { Rehberliğin toplumda } \\
\text { bana saygınlık } \\
\text { kazandıracağına } \\
\text { inanıyorum. }\end{array}$ & 3,69 & 4 & 4,3 & 7 & 7,5 & 25 & 26,9 & 34 & 36,6 & 23 & 24,7 \\
\hline $\begin{array}{l}\text { Rehberlik mesleği ile } \\
\text { ilgili olan bu bölümü } \\
\text { seçmiş } \\
\text { hoşnudum. }\end{array}$ & 3,65 & 5 & 5,4 & 7 & 7,5 & 26 & 28,0 & 32 & 34,4 & 23 & 24,7 \\
\hline $\begin{array}{l}\text { Rehberlik mesleğinin } \\
\text { gereklilikleri } \\
\text { konusunda kendime } \\
\text { güveniyorum. }\end{array}$ & 3,63 & 4 & 4,3 & 7 & 7,5 & 26 & 28,0 & 38 & 40,9 & 18 & 19,4 \\
\hline $\begin{array}{l}\text { Rehberliği profesyonel } \\
\text { bir şekilde } \\
\text { yürütebileceğime } \\
\text { inanıyorum. }\end{array}$ & 3,63 & 1 & 1,1 & 13 & 14,0 & 27 & 29,0 & 30 & 32,3 & 22 & 23,7 \\
\hline
\end{tabular}

Turizm Rehberliği

Birinci Sınıf

Öğrencilerinin

Mesleki Beklentileri

- 45 


\begin{tabular}{|c|c|c|c|c|c|c|c|c|c|c|c|}
\hline $\begin{array}{l}\text { Rehberlik mesleğinin } \\
\text { devamlılı̆ı } \\
\text { güven veriyor. }\end{array}$ & 3,48 & 4 & 4,3 & 13 & 14,0 & 25 & 26,9 & 36 & 38,7 & 15 & 16,1 \\
\hline $\begin{array}{l}\text { Rehberliğin çalışma } \\
\text { koşulları bana çekici } \\
\text { geliyor. }\end{array}$ & 3,36 & 10 & 10,8 & 7 & 7,5 & 32 & 34,4 & 27 & 29,0 & 17 & 18,3 \\
\hline $\begin{array}{l}\text { Zor şartlar altında dahi } \\
\text { rehberlik } \quad \text { yapmak } \\
\text { isterim. }\end{array}$ & 3,22 & 10 & 10,8 & 14 & 15,1 & 30 & 32,3 & 23 & 24,7 & 16 & 17,2 \\
\hline $\begin{array}{l}\text { Rehberliğe karşı özel } \\
\text { bir yeteneğim olduğu } \\
\text { kanısındayım. }\end{array}$ & 3,21 & 2 & 2,2 & 15 & 16,1 & 45 & 48,4 & 23 & 24,7 & 8 & 8,6 \\
\hline $\begin{array}{l}\text { Rehberlik mesleğinin } \\
\text { bana sıkıntılar } \\
\text { yaşatmasından endişe } \\
\text { duyuyorum. }\end{array}$ & 3,09 & 9 & 9,7 & 18 & 19,4 & 35 & 37,6 & 17 & 18,3 & 14 & 15,1 \\
\hline
\end{tabular}

Ümit ŞENGEL ve Burhanettin ZENGIN, 4 (1) 2020

- 46

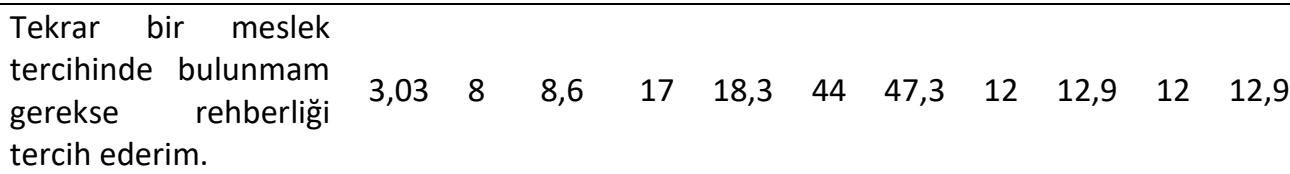

\begin{tabular}{llllllllllll}
\hline $\begin{array}{l}\text { Rehberliğin bana } \\
\text { uygun bir meslek } \\
\text { olmadığını } \\
\text { düşünüyorum. }\end{array}$ & 2,37 & 25 & 26,9 & 29 & 31,2 & 26 & 28,0 & 5 & 5,4 & 8 & 8,6 \\
\hline $\begin{array}{l}\text { Rehberliğin bana göre } \\
\text { bir meslek olmadığını } \\
\text { düşünüyorum. }\end{array}$ & 2,26 & 27 & 29,0 & 33 & 35,5 & 21 & 22,6 & 5 & 5,4 & 7 & 7,5 \\
\hline $\begin{array}{l}\text { Rehberliğin yaşam } \\
\text { tarzıma uygun } \\
\text { olmadığını } \\
\text { düşünüyorum. }\end{array}$ & 2,25 & 31 & 33,3 & 30 & 32,3 & 15 & 16,1 & 11 & 11,8 & 6 & 6,5 \\
\hline $\begin{array}{l}\text { Rehberlik mesleği } \\
\text { bana sıkıcı geliyor. }\end{array}$ & 2,15 & 29 & 31,2 & 38 & 40,9 & 14 & 15,1 & 7 & 7,5 & 5 & 5,4 \\
\hline $\begin{array}{l}\text { Rehberlik mesleğini } \\
\text { seçtiğime pişman } \\
\text { oluyorum. 2,15 }\end{array}$ & 33 & 35,5 & 26 & 28,0 & 25 & 26,9 & 5 & 5,4 & 4 & 4,3 \\
\hline $\begin{array}{l}\text { Rehberliğin kişiliğime } \\
\text { uygun olamadığını } \\
\text { düşünüyorum. }\end{array}$ & 2,12 & 36 & 38,7 & 31 & 33,3 & 12 & 12,9 & 6 & 6,5 & 8 & 8,6 \\
\hline
\end{tabular}


Tablo 2 incelendiğinde bazı ifadelerdeki katılım düzeyinin çok yüksek ve çok düşük olması dikkat çekmektedir. Örneğin rehberlikle ilgili olumlu beklentileri tanımlayan "rehberlik mesleğinde karşılaşacağım zorlukları aşabileceğime inanıyorum", "bilgili ve yeterli bir rehber olacağımı düşünüyorum" ve "rehber olma düşüncesi bile bana cazip geliyor." ifadelerindeki olumsuz görüşlerin tamamı \% 10'nun altındadır. Buna karşın rehberlik mesleğine ilişkin olumsuz görüş içeren ifadelerden "rehberlik mesleğini seçtiğime pişman oluyorum", "rehberlik mesleği bana sıkıcı geliyor", "bir meslek tercih etme durumunda olanlara rehberliği tavsiye etmem" ve "rehberliğin bana göre bir meslek olmadığını düşünüyorum" ifadeleri için toplam olumlu görüş \%10 seviyeleri ve altındadır.

Tablo 3: Öğrenci Beklentilerinin Cinsiyete Göre Farklılıkları

\begin{tabular}{|c|c|c|c|c|c|}
\hline Boyutlar & Değişken & $\begin{array}{l}\text { Sayı } \\
\text { (N) }\end{array}$ & A. Ort. & $\begin{array}{l}\text { T } \\
\text { Değeri }\end{array}$ & $\begin{array}{l}\text { P } \\
\text { Değeri }\end{array}$ \\
\hline \multirow{2}{*}{$\begin{array}{l}\text { Rehber olma düşüncesi bile bana cazip } \\
\text { geliyor. }\end{array}$} & Kadın & 39 & 4,00 & \multirow{2}{*}{2,45} & \multirow{2}{*}{0,016} \\
\hline & Erkek & 54 & 3,51 & & \\
\hline \multirow{2}{*}{$\begin{array}{l}\text { Rehberliğin bir şeyler üretip yaratmam için } \\
\text { bana fırsatlar vereceğini düşünüyorum }\end{array}$} & Kadın & 39 & 4,33 & \multirow{2}{*}{3,45} & \multirow{2}{*}{0,001} \\
\hline & Erkek & 54 & 3,55 & & \\
\hline \multirow{2}{*}{$\begin{array}{l}\text { Rehberlik yapan insanlara sempati } \\
\text { duyarım. }\end{array}$} & Kadın & 39 & 4,28 & \multirow{2}{*}{3,12} & \multirow{2}{*}{0,002} \\
\hline & Erkek & 54 & 3,62 & & \\
\hline \multirow{2}{*}{$\begin{array}{l}\text { Rehber olacağımı düşünmek beni mutlu } \\
\text { ediyor. }\end{array}$} & Kadın & 39 & 4,15 & \multirow{2}{*}{3,80} & \multirow{2}{*}{0,000} \\
\hline & Erkek & 54 & 3,37 & & \\
\hline \multirow{2}{*}{$\begin{array}{l}\text { Rehberlik yapan kişilerle sohbet etmekten } \\
\text { hoşlanırım. }\end{array}$} & Kadın & 39 & 4,33 & \multirow{2}{*}{3,19} & \multirow{2}{*}{0,002} \\
\hline & Erkek & 54 & 3,72 & & \\
\hline \multirow{2}{*}{$\begin{array}{l}\text { Bilgili ve yeterli bir rehber olacağımı } \\
\text { düşünüyorum. }\end{array}$} & Kadın & 39 & 4,00 & \multirow{2}{*}{2,31} & \multirow{2}{*}{0,023} \\
\hline & Erkek & 54 & 3,55 & & \\
\hline
\end{tabular}

Turizm Rehberliği

Birinci Sınıf

Öğrencilerinin

Mesleki Beklentileri

Tablo 3'te öğrenci beklentilerinin cinsiyetlerine göre olan farklılıkları verilmektedir. Araştırma kapsamında beklenti ölçen 27 ifadenin 6 tanesi cinsiyete göre anlamlı farklılık göstermektedir. Anlamlı farklılık gösteren 6 ifadenin tamamı turizm rehberliği okuyan öğrencilerin olumlu mesleki beklentileri ile ilgilidir. Farklılı̆ın nereden kaynaklandığının tespiti için aritmetik ortalamalar incelenmiş ve kız öğrencilerin erkek öğrencilere göre daha olumlu düşünmelerinden kaynaklanan bir anlamlı farklılığın olduğu tespit edilmiştir. Rehberlik okuyan kız öğrenciler erkeklere oranla daha fazla pozitif mesleki beklentilere sahiptir. 
Tablo 4: Öğrenci Beklentilerinin Bölümü Tercih Etme İsteğine Göre Farklılıkları

Ümit ŞENGEL ve Burhanettin ZENGIN, 4 (1) 2020

- 48

\begin{tabular}{|c|c|c|c|c|c|}
\hline Boyutlar & Değişken & $\begin{array}{l}\text { Sayı } \\
\text { (N) }\end{array}$ & A. Ort. & $\begin{array}{l}\mathbf{T} \\
\text { Değeri }\end{array}$ & $\begin{array}{l}\mathbf{P} \\
\text { Değeri }\end{array}$ \\
\hline \multirow{2}{*}{$\begin{array}{l}\text { Tekrar bir meslek tercihinde bulunmam } \\
\text { gerekse rehberliği tercih ederim. }\end{array}$} & Evet & 68 & 3,22 & \multirow{2}{*}{2,85} & \multirow{2}{*}{0,005} \\
\hline & Hayır & 25 & 2,52 & & \\
\hline \multirow{2}{*}{$\begin{array}{l}\text { Rehberliğin bana göre bir meslek } \\
\text { olmadığını düşünüyorum. }\end{array}$} & Evet & 68 & 3,89 & \multirow{2}{*}{2,32} & \multirow{2}{*}{0,022} \\
\hline & Hayır & 25 & 3,28 & & \\
\hline \multirow{2}{*}{$\begin{array}{l}\text { Rehberliğin yaşam tarzıma uygun } \\
\text { olmadığını düşünüyorum. }\end{array}$} & Evet & 68 & 3,95 & \multirow{2}{*}{2,88} & \multirow{2}{*}{0,005} \\
\hline & Hayır & 25 & 3,16 & & \\
\hline \multirow{2}{*}{$\begin{array}{l}\text { Rehberliğin kişiliğime uygun olmadığını } \\
\text { düşünüyorum. }\end{array}$} & Evet & 68 & 4,02 & \multirow{2}{*}{2,06} & \multirow{2}{*}{0,042} \\
\hline & Hayır & 25 & 3,44 & & \\
\hline \multirow{2}{*}{$\begin{array}{l}\text { Rehberlik mesleği ile ilgili olan bu bölümü } \\
\text { seçmiş olmaktan hoşnudum. }\end{array}$} & Evet & 68 & 3,82 & \multirow{2}{*}{3,11} & \multirow{2}{*}{0,003} \\
\hline & Hayır & 25 & 3,20 & & \\
\hline \multirow{2}{*}{$\begin{array}{l}\text { Rehberliğe karşı özel bir yeteneğim olduğu } \\
\text { kanısındayım. }\end{array}$} & Evet & 68 & 3,32 & \multirow{2}{*}{2,23} & \multirow{2}{*}{0,029} \\
\hline & Hayır & 25 & 2,92 & & \\
\hline
\end{tabular}

Turizm rehberliği okuyan öğrencilerin mesleki beklentilerinin bölümü istekli olarak tercih etme durumlarına göre farklılık analizleri tablo 4'te verilmektedir. Beklenti ölçen 27 ifadenin 6'sı bölümü istekli olarak tercih etme durumuna göre anlamlı farklılık göstermektedir. Aritmetik ortalamalar incelendiğinde bölüme isteyerek gelen öğrencilerin isteyerek gelmeyen öğrencilere oranla daha olumlu düşünmelerinden kaynaklanan bir farklılığın olduğu söylenebilir. Bu oldukça olağan bir sonuçtur. Çünkü öğrencilerin bölüm tercihlerini bilinçli ve isteyerek yapmaları ile mesleki beklentileri arasında doğrusal bir ilişkinin olduğu düşünülmektedir.

Tablo 5: Öğrenci Beklentilerinin Ailelerin Gelir Durumuna Göre Farklılıkları

\begin{tabular}{|c|c|c|c|c|c|c|}
\hline Boyutlar & & Değişken & $\begin{array}{l}\text { Sayı } \\
\text { (N) }\end{array}$ & A. Ort. & $\begin{array}{l}\mathbf{T} \\
\text { Değeri }\end{array}$ & $\begin{array}{l}\mathbf{P} \\
\text { Değeri }\end{array}$ \\
\hline \multirow{2}{*}{$\begin{array}{l}\text { Rehber olmayı } \\
\text { yakıştırıyorum. }\end{array}$} & \multirow{2}{*}{ kendime } & 3000 も ve Altı & 42 & 3,54 & \multirow[b]{2}{*}{$-2,398$} & \multirow[b]{2}{*}{0,019} \\
\hline & & $\begin{array}{l}3000 \quad \text { Ł'nin } \\
\text { Üstü }\end{array}$ & 51 & 4,05 & & \\
\hline \multirow{2}{*}{$\begin{array}{l}\text { Rehberlik mesleğinin } \\
\text { bana güven veriyor. }\end{array}$} & \multirow{2}{*}{ devamlıığı } & 3000 もve Altı & 42 & 3,14 & \multirow[b]{2}{*}{$-2,845$} & \multirow[b]{2}{*}{0,006} \\
\hline & & $\begin{array}{l}3000 \\
\text { Üstü }\end{array}$ & 51 & 3,76 & & \\
\hline
\end{tabular}


Turizm rehberliği öğrencilerinin beklentilerinin ailelerin aylık gelir durumuna göre farklılıkları ise tablo 5'te verilmektedir. Öğrenci beklentilerini ölçen toplam 27 ifadeden sadece 2 tanesi ailelerin gelir durumuna göre anlamlı farklılık göstermiştir. Aritmetik ortalamalar incelendiğinde anlamlı farklılık gösteren her iki ifade için de geliri yüksek olan ailelerin çocukları geliri düşük olanlara göre daha olumlu düşünmektedir.

\section{SONUÇ VE ÖNERILER}

Türkiye'de spesifik olarak turizm, yiyecek-içecek, otel ve konaklama gibi kelimelerin geçtiği bölümlerin tercih edilmeleriyle ilgili önemli bir sorunun olduğu söylenebilir. Bunların alternatifi olarak gastronomi, rehberlik ve rekreasyon gibi bölümler açılmakta ve bu bölümler öğrenci alınmaktadır. Dolaysıyla Türkiye'de turizm ile ilgili eski bölümlerin yaşadıkları problemlerin (tercih edilemem gibi), son birkaç yılın gözde bölümler olan turizm rehberliği ve gastronomi ve mutfak sanatları gibi bölümlerde yaşamaması oldukça önemlidir. Çünkü öğrenciler geleceklerini şekillendirmek ve yaşamlarının sonuna kadar hayatlarını etkileyecek olan sürece ilk adımı üniversite eğitimi ile atmaktadırlar. Dolayısıyla onların beklentilerini karşılayacak bir eğitim ve eğitim sonrasındaki süreci başarılı

Turizm Rehberliği Birinci Sınıf Öğrencilerinin Mesleki Beklentileri kılacak bir sistemin varlığı oldukça önemlidir. Böyle bir sistemde, çalıştıkları işte istediklerini bulamayan öğrenciler meslek değiştirme eğilimine sahip olabilmektedir. Fraser (2003), Türkay ve Yağcı (2007), Güzel ve arkadaşları (2014), Tekin ve Deniz (2015) ile Zengin ve arkadaşları (2017) yaptıkları çalışmalarda bu durumu destekleyen sonuçlar tespit etmişlerdir.

Turizm fakültelerinin son yıllarındaki gözde bölümlerinden olan turizm rehberliği bölümümün genel olarak bilindiği ve isteğe bağlı olarak tercih edildiği çalışmanın sonuçlarına yansımıştır. Üstelik çoğu zaman yakın çevresinde bu alanda veya bu alana yakın alanlarda çalışan veya eğitim gören bireyler olmadığı halde bölüm tercih edilmektedir. Ayrıca eğitim alan birinci sınıf öğrencilerinin mesleki beklentilerinin genel olarak olumlu olduğu da tespit edilmiştir Bununla birlikte kız öğrencilerin erkeklere, bölümü isteyerek tercih edenlerin etmeyenlere göre ve son olarak ise ailelerinin gelir durumu yüksek olanların olmayanlara oranla daha olumlu bir mesleki beklentiye sahip oldukları söylenebilir. Eğitim sürecinin bu beklentileri daha da arttıracağı düşünülmektedir. Raffaelli ve Koller (2005), Prior ve Cox (2014) ile Şengel ve arkadaşları (2015) bu sonucu destekler tespitlerde bulunurken, Erdem ve Kayran (2013) bu sonucun tersine sonuçlar tespit etmişlerdir.

Turizm rehberliği bölümlerinin sürekli tercih edilmesini sağlamak için bazı çalışmaların yapılması gerekmektedir. Bu çalışmalar genellikle eğitim ile 
Ümit ŞENGEL ve Burhanettin ZENGIN,

4 (1) 2020

- 50 veya turizm rehberliği mesleğinin işleyişi ile ilgilidir. Bu kapsamda araştırmanın bulguları da dikkate alınarak konuya ilişkin aşağıdaki öneriler geliştirilmiştir;

- Kamu ve özel sektörün ortak çalışmalar yaparak turizm rehberliği eğitimi alan öğrencilere umutlu olacakları bir gelecek inşa etmeleri gerekmektedir. Örneğin Turizm fakültelerindeki yabancı dil ve bilgisayar laboratuvarları ve adaptasyon programları gibi faaliyetler geliştirilebilir.

- Turizm rehberliği mesleğinin standartları ve işleyişi hakkında eksik olan yasal düzenlemelerin yapılması yararlı olabilir.

- Mesleğe sadece turizm rehberliği mezunu mensupların alınması özendirilmelidir.

- Farklı dillerde rehberlik yapmaya istekli olan rehberlik mezunları devlet tarafından teşvik edilebilir ve desteklenebilir. Böylece kokartsız ve rehber olmayan bireylerin çalıştırılmasının önüne geçilebilir.

- Üniversitelerde turizm ile ilgili birimlerin planlama dâhilinde çalışması gerekmektedir. Plan ve politikalardan yoksun, sadece bölüm açma ve kontenjan doldurma gayesi ile hareket etmekten kaçınılmalıdır.

- Illgili kamu kurumları, söz konusu bölümleri iş imkânları ve talep edilebilirlik durumları göz önünde bulundurularak kontenjan dengesi sağlayabilir.

- Üniversiteler öğrencilerin mesleğe ilişkin olumlu bir tutum içinde olmaları ve kendilerini geliştirmelerini sağlayacak eğitim ve adaptasyon programları düzenleyebilir.

- Son olarak ise konunun uzmanı olan araştırmacıların yaptıkları çalışmalarla konuyu sık sık gündeme getirmeleri faydalı olabilir. Özellikle bölümün talep edilebilirliğini sürdürülebilir kılacak çözüm önerileri sunan başka çalışmaların da yapılması yarar sağlayabilir.

\section{KAYNAKÇA}

Akman, Y. (1992). Hacettepe Üniversitesi Eğitim Fakültesi öğrencilerinin Meslek, Evlilik ve Geleceğe Yönelik Beklentileri. H. Ü. Eğitim Fakültesi Dergisi, (7): 125-149 
Buyruk, L. (2009). Turizm Lisans Eğitimi Alan Öğrencilerin Kariyer Beklentileri Üzerine Bir Araştırma. 10. Ulusal Turizm Kongresi, Mersin, s. 977-990.

Can, A. (2014). SPSS ile Bilimsel Araştırma Sürecinde Nicel Veri Analizi. Ankara: Pegem Akademi Yayınları

Çetin, G. G., Dönmez, D. ve Küçükaltan D. (2010). Turizm Alanında Eğitim Gören Öğrencilerin Kariyer Hedefleri: Ön Lisans Öğrencileri Üzerine Bir Araştırma. 11. Ulusal Turizm Kongresi, Kuşadası, s.351-363.

Dilbaz, N. ve Seber, G., (1993). Umutsuzluk Kavramı: Depresyon ve Intiharda Önemi. Kriz Dergisi, 1(3): 134-138.

Duman, T., Tepeci, M. ve Unur, K. (2006). Mersin'de Yükseköğretim ve Orta Öğretim Düzeyinde Turizm Eğitimi Almakta Olan Öğrencilerin Sektörün Çalışma Koşullarını Algılamaları ve Sektörde Çalışma

Turizm Rehberliği

Birinci Sınıf Öğrencilerinin Mesleki Beklentileri İsteklerinin Karşılaştırmalı Analizi. Anatolia: Turizm Araştırmaları Dergisi, 17(1): 51-69.

Dursun, S. ve Aytaç, S. (2012). Üniversite Öğrencilerinin İşgücü Piyasasına Yönelik Beklentileri Ve iş Deneyimleri ile Umutsuzluk Ve Kaygı Düzeyleri Arasındaki iliş̧ki Üzerine Bir Araştırma. СBÜ Sosyal Bilimler Dergisi, 10(1): 371-388

Eker, N., Işkın, M., Şengel, Ü. ve Zengin, B. (2015). Lisans Düzeyinde Eğitim Alan Turizm Öğrencilerinin Staj Sorunları Üzerine Bir Araştırma: Sakarya Üniversitesi Örneği. 2. Uluslararası Turizm ve Yönetim Araştırmaları Kongresi Bildiriler Kitabı, Kuşadası, ss. 863-875

Erdem, B. ve Kayran M. F. (2013). Balıkesir Üniversitesi Turizm İşletmeciliği ve Otelcilik Yüksekokulu Öğrencilerinin Meslek Seçimini Etkileyen Faktörler Üzerine Bir Araştırma. C.Ü. İktisadi ve İdari Bilimler Dergisi, 1(14): 81-106.

Fraser, Rick A. (2003), Why Don't Hospitality Students Keep The Faith? A Research Report On Hospitality Students' Commitment To Careers in The Industry. Managing Employee Attitudes And Behaviors In The Tourism And Hospitality Industry, Ed. By Salih Kusluvan, Nova Science Publisher, New York.

Guest, M. ve Duyen, L. T. H. (2016). Student Preferences, Expectations and Anxieties Regarding an Online Exchange Program: Reports from Japan and Vietnam. 3L: The Southeast Asian Journal of English Language Studies, 22(1): $67-79$ 
Ümit ŞENGEL ve Burhanettin ZENGIN, 4 (1) 2020

- 52
Güzel, T., Akdağ, G., Güler, O. ve Şener, S. (2014). Turizm Eğitimi Alan Öğrencilerin Turizmde Kariyer Algılamaları: Çanakkale, Mersin ve Kıbrıs'ta Bir Araştırma. 3. Doğu Akdeniz Sempozyumu, ss:176-187, Mersin. ISBN:978-605-4940-06-6

Kokt, D. ve Strydom, A. J. (2014). Reflecting On Industry And Student Expectations For Working in the Tourism And Hospitality Industry: A Case Study. South African Journal for Research in Sport, Physical Education and Recreation, 36(1): 119-130.

Prior, K. ve Cox, A. S: (2014). Students' Expectations of Ageing: An Evaluation of the Impact of Imagined Intergenerational Contact and the Mediating Role of Ageing Anxiety. Journal of Experimental Social Psychology 55: 99-104

Raffaelli, M. ve Koller, S.H., (2005). Future Expectations of Brasilian Street Youth. Journal of Adolescence, 28(2): 249-262.

Saw, A., Berenbaum, H. ve Okazakic, S. (2013). Influences of Personal Standards and Perceived Parental Expectations on Worry for Asian American and White American College Students, Anxiety, Stress, \& Coping, 26(2): 187-202

Şahin, S. ve Acun, A. (2016). Turizm Rehberliği Öğrencilerinin Mesleğe Yönelik Tutumları. Gaziantep University Journal of Social Sciences, 15(2):563-580

Şengel, Ü., Pamukçu, H. ve Sarışık, M. (2015). Lisans Düzeyinde Eğitim Alan Turizm Öğrencilerinin Staj Sorunları Üzerine Bir Araştırma: Sakarya Üniversitesi Örneği, 2nd International Congress of Tourism \& Management Researches Proceeding Book, 01-03 Mayıs Kuşadası/Türkiye, s. 890-903

$\begin{array}{llll}\text { TDK (Türk } \quad \text { Dil } & \text { Kurumu). }\end{array}$ http://www.tdk.gov.tr/index.php?option =com_gts\&kelime=BEKLENT\%C4\%BO, Erişim Tarihi: 20 Nisan 2019)

Uluçay, T., Özpolat, A.R., İ̧̧gör, i.Y. ve Taşkesen, O. (2014). Lise Öğrencilerinin Gelecek Beklentileri Üzerine Bir Araştırma. E-Journal of New World Sciences Academy, 9(2): 234-247.

Tekin, Ö. A. ve Deniz, í. (2015). Turizm Öğrencilerinin Yiyecek ve İçecek Departmanına Yönelik Tutumları: Üniversite Öğrencileri Üzerine Bir Inceleme. Elektronik Sosyal Bilimler Dergisi,. 55(14): 178-197. 
Terzi, A. Rıza. ve Tezci, E. (2007). Necatibey Eğitim Fakültesi Öğrencilerinin Öğretmenlik Mesleğine İlişkin Tutumları. Educational Administration: Theory and Practice, 52: 593- 614.

Türkay, O. ve Yağcı, K. (2007). Turizm Eğitimi Alan Öğrencilerin Okulda ve Turizm Sektöründe "Öğrenme"lerinin Sektörden Ayrılma Eğilimlerine Etkisi, Dokuz Eylül Üniversitesi Sosyal Bilimler Enstitüsü Dergisi, 9(4): 219-246

Yazıcıoğlu, Y. ve Erdoğan, S. (2004). SPSS Uygulamalı Bilimsel Araştırma Yöntemleri. Ankara: Detay Yayıncılık.

Zengin, B., Şen L. M. ve Taşar, O. (2011). Marmara Bölgesinde Turizm Lisans Öğrencilerinin Konaklama Sektöründe Cinsiyete Göre Kariyer Düşünceleriyle Illgili Bir Araştırma, International Conference On Eurasian Economies Tebliğ Kitabı, SESSION 3B: Turizm ve Mikroekonomi, ss: 217-225

Zengin, B. Işkın, M. ve Şengel, Ü. (2017). Ailelerin Sosyo-Ekonomik Durumlarına Göre Turizm Eğitimi Alan Öğrencilerin Meslek Değiştirme Eğilimlerinin Belirlenmesi, 3. Turizm Şurası Bildiriler Kitabı, Cilt 2, 402-413, Ankara

Turizm Rehberliği

Birinci Sınıf

Öğrencilerinin

Mesleki Beklentileri

\section{ETIK Ve BILIMSEL ILKELER SORUMLULUK BEYANI}

Bu çalışmanın tüm hazırlanma süreçlerinde etik kurallara ve bilimsel atıf gösterme ilkelerine riayet edildiğini yazar(lar) beyan eder. Aksi bir durumun tespiti halinde Güncel Turizm Araştırmaları Dergisi'nin hiçbir sorumluluğu olmayıp, tüm sorumluluk makale yazar(lar)ına aittir. 